\title{
The spirit of sauna: legitimating the Finnish place brand
}

Legitimating the Finnish place brand

\author{
Jack S. Tillotson \\ Department of Marketing, School of Marketing and Communication, \\ University of Vaasa, Vaasa, Finland \\ Vito Tassiello \\ Faculty of Business and Law, Liverpool Business School, \\ Liverpool John Moores University, Liverpool, UK \\ Alexandra S. Rome \\ Department of Marketing, ICN Business School, Nancy, France, and \\ Katariina Helaniemi \\ Department of Marketing, Aalto University Business School, Aalto, Finland
}

\begin{abstract}
Purpose - The purpose of this paper is to investigate inhabitants of Finland and their continuing efforts to narrate a national identity within the constraints imposed by discursive meanings of Finnish culture through the experience of sauna.

Design/methodology/approach - Data collection comprised semi-structured interviews with Finnish local residents and entrepreneurs; these were supplemented with secondary data including books, articles, advertisements and documents referencing sauna in the context of Finland.

Findings - The analysis and interpretation by the authors show that the symbolic resource of sauna constitutes the legitimation of Finnish nation branding discourses at three levels: regulative, normative and cultural-cognitive; we label these sauna governance, communal identity creation and mythmaking, respectively.

Originality/value - The research contribution reveals that nation branding discourses are also forms of legitimation work. Finnish nation branding discourses are interwoven with sauna as the symbolic resource of "Finnishness" and become conduits for the expression of discursive meanings. This demonstrates that institutional legitimacy is an intrinsic aspect of the ways place branding discourses can be used as a mode of governance (i.e. a policy instrument).
\end{abstract}

Keywords Institutional theory, Legitimation, Nordic, Place branding discourses, Sauna,

Symbolic resources

Paper type Research paper

\section{Introduction}

A place brand identity is not a mere assortment of cognitive and emotional associations (Kavaratzis and Hatch, 2013). Rather, it refers to the meanings appropriated through

(C) Jack S. Tillotson, Vito Tassiello, Alexandra S. Rome and Katariina Helaniemi. Published by Emerald Publishing Limited. This article is published under the Creative Commons Attribution (CC BY 4.0) licence. Anyone may reproduce, distribute, translate and create derivative works of this article (for both commercial and non-commercial purposes), subject to full attribution to the original publication and authors. The full terms of this licence may be seen at: http://creativecommons.org/ licences/by/4.0/legalcode

Received 13 December 2019 Revised 25 February 2020 12 May 2020 Accepted 15 May 2020

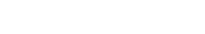


communication and culturally recognisable resources, such as character types, symbolic resources and plot lines that are entangled with places in narrative and discursive processes (Cassinger and Eksell, 2017). Collectively, these cultural resources are managed to build the image or identity of a place - city or region - in a positive way, which confers what is commonly described as reputation (Bell, 2016). For example, "Nordicness", as a place brand, is unique in that its reputation is not confined to a region, but is rather an idea that transverses geographical bounds (Cassinger et al., 2018; Pietilä et al., 2019). At the heart of this "reputational capital" (Bell, 2016), symbolic resources function as conduits for place branding discourses and expressions of discursive meanings (Kaneva, 2011; Varga, 2013). Cassinger et al. (2016, p. 181) argue that the meaning-making process connected to nation branding resources (ideas, practices or configurations) is dynamic, that is contextually, temporally and spatially bound. While foregrounding the role of institutional actors, they maintain that this process requires consensus, mutual understanding and "support from the population". The meaning of place branding and regionalisation discourse depends, therefore, not only on the institutional context but also on the citizen participants who shape and reiterate what is legitimate or "desirable, proper, or appropriate" (Suchman, 1995, p. 574).

The purpose of this study is to explore institutional legitimation processes in the production of Finnish national identity through place branding discourses. The institutional legitimacy of a place branding discourse is an ongoing set of individual and social processes established in an apparent collective acceptance by local community members as desirable or suitable (Brown and Toyoki, 2013; Suchman, 1995). Substantial research has been devoted to understanding the external legitimacy of place brands; this includes the ecology or environments that place brands exist, their envelopment in neoliberal discourses (Lucarelli, 2018; Varga, 2013), as well as the various stakeholders involved, including government regulators, foreign diplomacy makers, marketers, tourists, transnational corporations, product brands and employees (Cassinger et al., 2016; Morgan et al., 2003). Far less attention has been paid to internal legitimacy, afforded by a nation's inhabitants or residents (Braun et al., 2013; Lichrou et al., 2017; Warnaby and Medway, 2013), and its import for the stability and institutionalisation of place branding discourses. The relevance of this, we suggest, sits in uncovering how place branding discourses may function as a form of internal legitimation for national identity among internal stakeholders who, until now, have been underexamined; and how this discursive work unfolds around symbolic resources, co-constituting place brands through bottom-up processes of legitimation work.

Building on previous research adopting a cultural approach (Bianchini and Ghilardi, 2007), place branding is understood as a dynamic communication process whereby the institutional legitimation of national identity can be seen as a policy instrument (Lucarelli and Giovanardi, 2014). Understanding legitimation work as a malleable discursive resource embedded in a dynamic interplay of consensus and contestation, "talked and written continuously into and out of existence" through place branding discursive work (Brown and Toyoki, 2013, p. 867), becomes relevant as language is a significant "medium of social control and power" that represents modes of brand governance (Fairclough, 1989, p. 3). As place-branding studies have generally prioritised external stakeholders (Warnaby and Medway, 2013), far less attention has been paid to local voices and how they sustain and repudiate "existing social and power relations" through processes of governance (Fairclough, 1995, p. 77).

Based on an in-depth case study of sauna in Finland, we attend to these underexamined internal stakeholders, analysing how inhabitants' talk functions as internal legitimacy work. 
Of particular interest is how inhabitants narrate a national identity within the constraints imposed by symbolic cultural artefacts. Sauna offers rich opportunities for research and theory building in place branding studies, not least because sauna is a regionally based phenomenon requiring sensitivity to both place and history.

The remainder of this paper is organised as follows. First, relevant research is reviewed on legitimacy and symbolic resources with a focus on how these concepts enrich the scholarship on place branding. Sauna is subsequently presented as a symbolic cultural resource through which we analyse the constitution of the Finnish nation branding discourses. Following a presentation of the methodology, the empirical analysis reveals that Finnish nation branding discourses and symbolic imaginaries of sauna constitute three kinds of institutional legitimacy: regulative, normative and cognitive. The concluding sections discuss the implications of internal legitimation and the role of symbolic resources in place branding discourses. Herein, we highlight that internal stakeholders may be used as a policy instrument to advance the common acceptance of a national identity.

\section{The role of legitimacy in the context of place branding}

Legitimacy is understood as "a generalised perception or assumption that the actions of an entity are desirable, proper or appropriate within some socially constructed system of norms, values, beliefs and definitions" (Suchman, 1995, p. 574). Simply stated, legitimacy refers to the process through which something (a belief, value, norm, product, idea, place, public policy, etc.) becomes commonly accepted. Contemporary theorising has examined three distinct pillars of legitimacy: regulative, normative and cultural-cognitive (Scott, 1995). Regulative legitimacy refers to the degree which discursive practice conforms to rules and regulations introduced by an intervening organisation, most commonly the government; normative legitimacy occurs when a practice or resource is viewed as congruous with the dominant norms and values of a particular place or community (Humphreys and LaTour, 2013); and cultural-cognitive legitimacy refers to the degree to which a practice or resource can be classified, understood, and integrated with existing cultural frameworks to make inhabitants' lives comprehensible (Suchman, 1995). Cultural-cognitive legitimacy is a subtle dimension of the legitimation process grounded on taken-for-granted understandings (Humphreys, 2010).

Much research on the legitimacy of place brands has focused on top-down processes, whereby branding is applied by urban leaders and cultural intermediaries to impose particular meanings which target foreign publics and tourists (Morgan et al., 2003). Others have explored degrees of wider social support for an institutionalised idea and the cultural pressures to conform to the expectations of external stakeholders while using place branding discourse as a policy instrument (Lucarelli and Giovanardi, 2014). More recently, scholarship has begun to consider participatory approaches (Kavaratzis and Kalandides, 2015; Zenker and Erfgen, 2014) and democratic legitimacy (Eshuis and Edwards, 2013) that stress the co-constitutive nature of place branding. While these studies have proven valuable in furthering understandings of citizens as participants in place branding processes, they tend to generally prioritise the agentic performance of citizens whilst overlooking discursive constraints, including the role of cultural artefacts (Cassinger et al., 2016) that help organise and naturalise cultural meanings. Thus, building on and extending previous research, the current study examines both the discursive practices and constraints by which inhabitants use sauna - as a symbolic resource - to shape Finnish place branding discourse from the bottom-up.
Legitimating the Finnish place brand

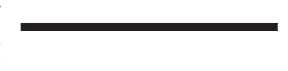




\section{Sauna as a symbolic resource}

Place branding discourses can be characterised as "the purposeful symbolic embodiment of information about a place in order to create associations and expectations around it" (Lucarelli and Berg, 2011, p. 21). Recent research has illustrated how symbolic resources can function as vehicles for institutionalising cultural meanings. For example, the British Royal Family successfully leverages key universal narratives, such as the fairytale genre and underdog romances, tapping into public sentiment as well as fuelling participation and engagement to institutionalise cultural meanings about Britain (Otnes and Maclaran, 2018). Likewise, Champagne has been characterised as a symbolic resource of France that binds global narratives in the creation of nation branding discourses and imaginaries (Rokka, 2017), enabling it to function as an integrative, communal resource (Charters and Spielmann, 2014). Accordingly, symbolic resources have the power to engage and integrate local actors, as well as normalise or conventionalise place branding discourses and practices.

We propose sauna is one such symbolic resource through which Finnish nation branding discourses organise and naturalise cultural meanings. Sauna is a Finnish bathing ritual that takes place in a dimly lit wood-panelled room whereby one ladles water over the heated stones of a stove to produce steam. A symbol of the Finnish national identity, the meanings of sauna developed as a political construction of the nineteenth century nationalist movement in Finland, during which the country struggled to identify itself amidst independence following 800 plus years of occupancy (Edelsward, 1991; Särkikoski, 2012). Poems and paintings throughout the 18th and 19th centuries contributed to the national sentiment and mythical qualities of sauna linking this to the national identity - or feeling of being Finnish (Särkikoski, 2012). This materialised in the three million saunas in the land of five million people that exist in Finland today (Bosworth, 2013). Ancillary references to sauna have been found in Finnish farming communities (Acerbi, 1802), cleanliness regulations for Finnish soldiers (Kaups, 1963), and recent guides outlining its physiological benefits in therapy (Hannuksela and Ellahham, 2001). As a historically oriented symbolic resource that underpins the emergence of a place brand (Giovanardi et al., 2013), sauna forms discursive patterns (or constellations of practices and material resources) that become commonly accepted as institutionalised cultural meanings of the Finnish nation.

The primary interests of the current study, therefore, sit in the communicative interaction between symbolic resources and discursive practices that co-constitute place brands. Discourse and language are useful tools for theorising within the interdisciplinary domain of place branding (Koller, 2008; Lucarelli and Giovanardi, 2014). Place branding indicates an interaction of territorial and symbolic features with public and private stakeholders as the "institutional shape" of a region emerge (Messely et al., 2013). Because institutional shapes are "constituted through discourse" and discourse analysis has often been used to theorise institutionalisation processes (Phillips et al., 2004, p. 635), the importance of language is key to the methodology adopted in this paper.

\section{Methodology}

This study was conducted from an interpretive perspective with the aim of producing a rich account of the role of sauna in the co-constitution of the Finnish national identity. Our approach is consistent with research adopting a discursive perspective to the processes of place branding (Lucarelli and Brorström, 2013). By focusing on the co-constitution of national identity through the dynamic relations between local discursive practices and symbolic cultural resources, we focus on the "linguistic involvement" of internal stakeholders in the formation of national identity (Lucarelli and Giovanardi, 2014). 
In analysing the reciprocal relations between inhabitants' talk and the cultural resources related to sauna, the situated accounts of research participants become culturally contextualised by patterns of discourse extending between and beyond larger sociohistorical frames of reference (Askegaard and Linnet, 2011).

Data was collected between December 2015 and August 2017. The main source of data for this study consisted of 13 semi-structured interviews, corresponding with our discursive approach in which we seek to understand how local inhabitants perceive sauna and how sauna shapes Finnish national identity. All interviews were recorded and transcribed, and respondents were given pseudonyms to ensure privacy. Of those interviewed formally (Table 1), five were women and eight were men and ages ranged from late 20 s to mid-60s, granting a unique perspective across genders and generations. Saunas, and especially public saunas, are most commonly found in urban environments; thus, participants were recruited from, in and around the most densely populated capital region of Helsinki, home to nearly $40 \%$ of the nation's population. Interviews followed a loose guide facilitating the emergence of organic themes introduced by the respondents (Spiggle, 1994). The initial focus of the investigation was to understand the role of public sauna in Finnish culture and its implications for contemporary consumption practices. Individuals with prolonged engagement with Finnish public saunas like owners, founders, employees and enthusiasts as well as casual visitors were recruited until no incremental insights were generated (Belk et al., 2013). During the course of this research, sauna was elevated to an "iconic" element of Finnish national identity, thus, place branding discourses became a salient theoretical context. As such, additional interviews were formally collected from cultural intermediaries including artists and journalists to triangulate the boundary conditions of the phenomenon (Belk et al., 2013).

In addition to the 13 formal interviews, other sources of data included informal discussions and observations, as well as books, articles, advertisements and documents with (historical) references to sauna in the context of Finland. Experiential data generated at the sauna locations themselves proved particularly valuable because it familiarised and oriented researchers to the sauna context and enriched knowledge of the Finnish disposition. Collectively, the breadth of data allowed for the idiosyncratic responses of those interviewed formally to be more easily contextualised and dominant patterns of shared meanings identified. These features are important because discourse analysis operates on the implicit level of people's background orientations and attempts to expose what they take as a matter

\begin{tabular}{|c|c|c|c|c|}
\hline Pseudonym & Gender & Age & Participant role & \\
\hline Aleksi & Male & 49 & President of a sauna association & \\
\hline Anna & Female & 28 & Filmmaker and sauna enthusiast & \\
\hline Antti & Male & 35 & Public sauna owner & \\
\hline Emma & Female & 37 & Director of a Finnish sauna club & \\
\hline Heidi & Female & 31 & Casual sauna user & \\
\hline Henri & Male & 45 & Journalist & \\
\hline Joel & Male & 29 & Photographer and sauna enthusiast & \\
\hline Lauri & Male & 55 & Public sauna owner & \\
\hline Leevi & Male & 51 & Vice President of a Finnish sauna club & \\
\hline Maria & Female & 43 & Sauna enthusiast & \\
\hline Risto & Male & 40 & Casual sauna user & Table 1. \\
\hline Sten & Male & 66 & Public sauna owner & Participant \\
\hline Tanya & Female & 30 & Sauna enthusiast & characteristics \\
\hline
\end{tabular}

Legitimating the Finnish place brand

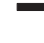


of fact by showing the different contingencies that organize their lives in meaningful ways (Fairclough, 1989).

Data analysis followed a continuous and flexible process that developed over the course of the research project (Spiggle, 1994). Early phases engaged with the interview transcripts through a form of emergent analysis (Belk et al., 2013). Each author read the transcripts independently and derived analytic codes that captured and organised respondents' salient experiences and meanings. Through on-going discussions among researchers and colleagues, codes were continuously refined and collapsed into broader themes and patterns (Spiggle, 1994). An iterative process moving between data and theory revealed legitimating statements surrounding sauna and the Finnish national identity. To emphasise this discursive process and tease out further analytic codes, a priori codes were developed around legitimacy processes (Suchman, 1995). In continued discussions between researchers, discursive practices surrounding sauna that constituted the institutional legitimacy of the Finnish place brand were identified.

\section{The legitimacy work of Finnish nation branding discourses}

In the following sections, we analyse the co-constitution of Finnish national identity through discursive activity connected to symbolic imaginaries of sauna at three emergent levels:

(1) sauna governance;

(2) sauna and communal identity creation; and

(3) sauna and mythmaking.

We attribute each of these analytic levels to a type of legitimacy work - negotiating regulative legitimacy, affirming normative legitimacy and mobilising cultural-cognitive legitimacy.

Sauna governance: negotiating regulative legitimacy.

Regulative legitimacy refers to the degree to which a practice conforms to explicit rules and policies (Humphreys and LaTour, 2013). The Kalevala, another cultural artefact tied to Finnish nationalism, was written to remind Finns of their cultural heritage and has numerous references to sauna. Written in 1835, the national epic is compiled of Finnish ballads, lyrical songs and incantations which highlight that the "sauna, or bath-house is always a separate building; and there, Finnish people take extremely hot baths almost every evening" (Kirby, 1907, p. 321). Kaups (1963, p. 496) describes how "other portions of the Kalevala refer to the use of the sauna for malt making, as a place for childbirth, and as a means of driving away evil".

Starting in the late 1940s, abreast Finland's industrial revolution, public saunas were built in apartment buildings throughout major cities and almost every block had their own. This was due, in large part, to the fact that after the Second World War, apartments did not have hot - or in some cases, any - water for showering. It was customary for inhabitants to queue for the sauna on Saturday evenings (Heikkinen, 2014). Saunas were often full and on Saturdays the queues often spilled out onto the street. Going to the sauna was thus considered a hygienic act and not necessarily the pleasant experience that it represents today.

Discursive practices identified at the level of regulative legitimacy conformed to explicit rules and procedures but not without some degree of contestation. Lauri, who owns of one of the oldest public saunas in Finland recounts: "Sauna was an essential part of the hygiene network still in the beginning of the 20th century". Consequently, the prices of sauna were 
regulated by the state up until the mid-1960s, to ensure they remained public and widely available. Plate 1, an announcement from 1948 by the Finnish Association of Commercial Saunas, provides details of how public sauna owners struggled with the state regulation. At the top, the poster reads, "Do sauna payments need to be raised? [Onko saunamaksuja korotettava?]". The poster portrays a historical look at the price of sauna versus particular expenses (e.g. the wood they use to burn in sauna stoves) from 1939 to 1948. It states that while the price of sauna entry has risen about $4 \%$ over ten years, the expense of wood has risen $16 \%$ over the same period. It is important to note that 1948 is directly after the Second World War. Finland was amidst an industry boom and devalued its currency several times to make exports more attractive to Western buyers; this simultaneously led to heavy domestic inflation (Pihkala, 1999). The poster reflects this inflation by noting that sauna buckets, 20 Finnish Marks in 1939, are now up to 850 Finnish Marks, "if you can even find one [sattuu löytämään]"! The poster goes on to describe the struggles public sauna owners faced amidst domestic inflation and government regulated entry prices.

Price regulation, while ensuring the popularity of public saunas, did not contribute to the cleanliness. As Lauri recalls: "[Some of the public saunas] were rather dirty and unpleasant. And due to the regulated prices, the owners could not afford the upkeep necessary to maintain cleanliness standards". This, in part, led to institutional regulations and

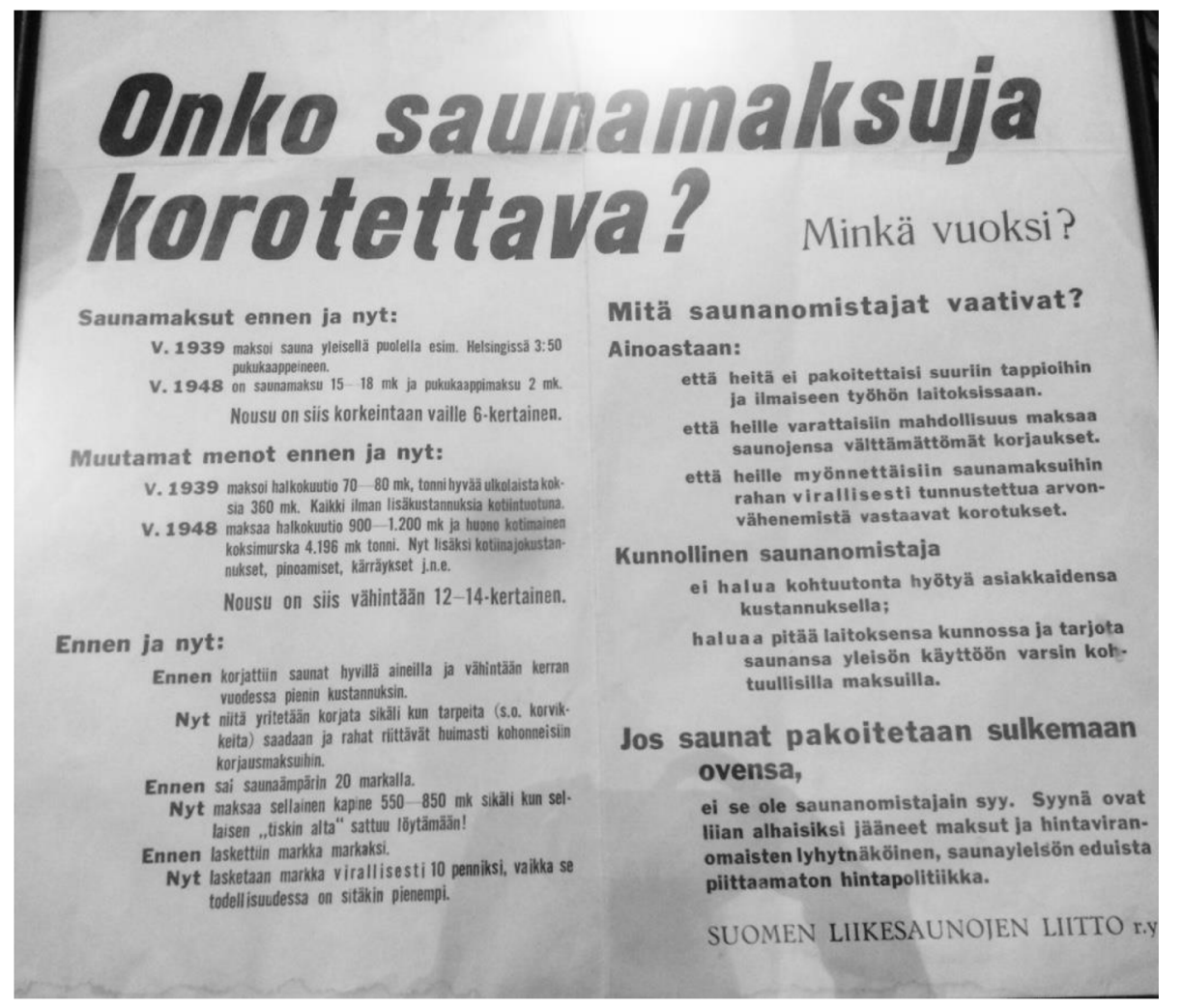

Legitimating the Finnish place brand
Plate 1.

Announcement about price regulation concerning public saunas

Source: Photo by Katariina Helaniemi (co-author) (2015) 
architectural structures that enforced acceptable etiquette (Foucault, 1995/1975), which in the context of this research, emphasised cleanliness and purity. For example, traditional Finnish rules dictated that "sex should not be discussed in the sauna" (Sten, public sauna owner). Accordingly, saunas typically had separate rooms for female and male users, with some larger saunas offering private "family" rooms. Henri, a journalist for a Finnish Broadcasting Company, explains that such family rooms reinforced cultural norms dictating appropriate male and female socialisation in the sauna:

Couples were allowed to join the 'family' saunas, but there were strict rules that non-married couples had to go to separate sides. Young couples would often rent so-called 'sauna-rings' that represented marital status, so as to show the sauna owners that they were family.

In his legitimation work, Henri highlights how couples negotiated gender regulations in ways that reinforced and strengthened the sanctity of marriage by wearing fake rings. In a related vein, Saarenmaa (2014) highlights how the male dominated Finnish political elite have affected the structural and symbolic meanings of sauna, which has become an integral part of Finnish diplomacy - an ideal place to gather, bathe, make deals and drink (Ministry for Foreign Affairs, 2011). While today, the sauna experience may be associated with the consumption of (typically small amounts) alcohol, this was prohibited in public saunas during Finland's transition to industrialism (Heikkinen, 2014). Consequently, some owners found that certain architectural alterations had to be made to enforce the dry policies of the premises:

The men's side of Arla Sauna was switched to the second floor because people smuggled alcohol to the sauna through the first-floor window (Lauri, public sauna owner).

These descriptions of architectural structures of sauna may be interpreted as a mode of governance in the Foucauldian sense. Extending the metaphor of the panopticon (Foucault, 1995/1975), saunas are designed in such a way that people negotiate taken-for-granted notions (Humphreys, 2010) of institutionalised gender forms (Saarenmaa, 2014) and sauna diplomacy (Ministry for Foreign Affairs, 2011), altering their behaviour via self-regulating tactics that influence patterns of normality and deviance. Social institutions, like public saunas, become productive of subjects who are "normalised", something we expand on in the following section, through disciplinary acts that regulate numerous aspects of their everyday lives from the bottom-up.

\section{Sauna and communal identity creation: affirming normative legitimacy}

Normative legitimacy is credited to a symbolic resource on the basis of a positive normative evaluation whereby sauna, in this case, is viewed as socially acceptable according to dominant norms and values (Humphreys and LaTour, 2013). The Nordic heritage of communalism (Weijo et al., 2018) manifests itself through a collective urban city culture and has deemed the public sauna a common meeting point. This began during Finnish urbanisation of the 1950s and 1960s when mass migrations of people moved from the countryside into city centres. Apartment buildings were the standard urban dwelling and residents began using public saunas as meeting grounds (Heikkinen, 2014).

For example, Sompasauna - a sauna located in an empty industrial area of Helsinki - is maintained entirely by volunteers who keep it free for public use (Plate 2). As one sauna enthusiast and Sompasauna community member notes:

According to the legend, Sompasauna was originally built by three Helsinki-born men, who found a sauna stove. A community quickly formed around it. In 2013, the community founded an association for Sompasauna and made it official in order to prevent the city from tearing the sauna down during the summer (Joel). 


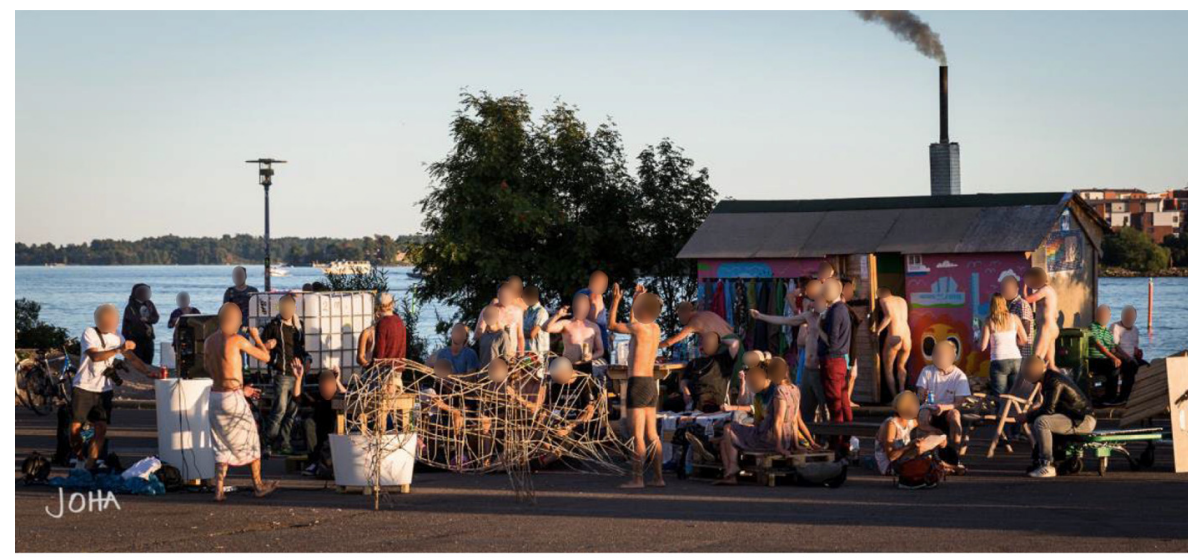

Source: Photography by Joha Gronvall (2016) permissions received

Plate 2. Sompasauna

Joel's legitimation work highlights the transformation of normative perceptions of sauna from a hygienic place to a common gathering ground. In contemporary times, the sauna has become a place for congregation; a meeting point for urban subcultures and younger generations. Sompasauna, for example, is seen as a resistance and contestation to traditional bureaucracy (Dzenovska, 2005; Graan, 2013); a creation of normative urban culture where citizens take ownership of Finnish national identity by instilling a sense of community in urban areas where enthusiasts resemble, in some ways, brand ambassadors (Braun et al., 2013).

Sauna communities embrace heterogeneity and inclusiveness (Thomas et al., 2013). Members are bound together by their devotion to the sauna ritual and norms of practice, which they feel an obligation to champion and promote. As a bathing practice, sauna is traditionally done in the nude; yet Lauri's legitimation work highlights an initiative to enhance the sauna practice, making it more inclusive, whereby bathing suits are used to increase the comfort level of outsiders:

As a place of national identity creation, sauna has given rise to places like Sompasauna, but also other public saunas that are focused on inclusiveness. For instance, Arla Sauna has organised separate sauna shifts to immigrants where the participants have had the possibility to go to sauna with their swimwear on (Lauri, sauna owner).

Lauri underscores how sauna communities integrate and acculturate immigrants into the Finnish lifestyle by way of Nordic consensus culture (Tillotson and Martin, 2015). The popularity of the public sauna is growing and with the increase of communal values, new establishments are opening up regularly (Bosworth, 2013). The Kulttuurisauna (or cultural sauna), for example, is promoted as a tourist destination and attraction of Helsinki that provides a warm, relaxing atmosphere where people can learn the sauna ritual.

In addition to public saunas, housing associations and large apartment buildings often have communal sauna times called lenkkisauna. Anna, a filmmaker and sauna enthusiast, describes:

Lenkkisauna is like a weekly gathering or social event with neighbours. Sauna is sort of filling the needs for social interaction within the community. These weekly sauna sessions have been a place where women who live in the apartment building go together and meet each other to hear the rumours and to keep up with what is going on in the community. 
Today, community is a core function of sauna, affirming values associated with relaxation and socialisation, as opposed to cleanliness and hygiene.

\section{Sauna and mythmaking: mobilising cognitive legitimacy.}

The Finnish national identity began materialising as the nation claimed independence in 1917 after centuries of Swedish and then Russian occupation (Tillotson and Martin, 2015). Development of the Finnish identity was a struggle because up to that point, most of the cultural symbols of Finland were Swedish, including the national anthem (Peltonen, 2000). Arising out of this transition, Finland emerged as one of the top-performing nations by embracing the legacy of the Nordic welfare state, egalitarianism, and "commonness in which everybody - high and low - strive to be able to identify with the middle" (Kjeldgaard and Östberg, 2007, p. 184). This sentiment was shared by many respondents who often stress the need for "balance" and well-being as imagined through the ritual of sauna. Likewise, increasing academic articles and the popular press has brought attention to the utopian quest of Nordic Exceptionalism, highlighting egalitarian notions of well-being that positions the Nordic region at the top of the list when it comes to education, parenthood, women's rights and retirement (Cassinger et al., 2018; Weijo et al., 2018).

Yet, the rise to the top has not come without contestation. For many, the benefits of urban life do not outweigh its stresses and the pendulum of well-being is often out of balance. Because Finland moved through a rapid industrialisation and urbanisation process on the back of the Second World War (Peltonen, 2000), large sections of the population were uprooted from farms to urban centres, whereby people struggled to adjust to the urban lifestyle and longed for their rural roots (Ilmonen, 1988). For many of our respondents, the city life offers oppressive civil orders and, according to sauna enthusiast Tanya, is an "enemy to good health". Work-life associated with urbanism is particularly stressful and many feel the need to relax as a way to "get [their] $\operatorname{mind}[s]$ off work and everything that is stressful connected to work" (Heidi, casual sauna user).

To escape the stresses of urban life and restore a desired balance, sauna is used as a mythic or purification ritual bridging humanity and nature. In her legitimation work, Tanya notes, "it's the place where everything comes together". Maria, a sauna enthusiast, refers to sauna as a "holy place [that] shows the power of nature". Similarly, for Risto, a casual sauna user, bathing in hot sauna is something "primitive. [. . . Sauna is like a church and hospital and clinic. You clean your body and your mind all in one". Even the language surrounding sauna implicates religious and sacred motifs (Belk et al., 1989), such as löyly, the Finnish word for the steam produced in the sauna, which also means soul or spirit.

Even prior to Finnish national independence, the sauna was the first room built in any Finnish home because the sauna experience is believed to open the door to new vantage points, bringing deeper meaning to activities like swimming, fishing and foraging. Sauna is believed to mobilise a socio-spatial transformation (Hirschman et al., 2012), whereby nature becomes the provider of sustenance both materially and spirituality. This finds further historical reference in the previously mentioned Kalevala, written to remind Finns of a cultural heritage intrinsically linked to nature and the forest. Finnish folklorist, Irma-Riitta Järvinen, notes that a:

[...] distinguishing feature of the Kalevala was the animate quality of the natural world and its inhabitants: animals and plants speak and act, and so do objects such as boats and swords (Järvinen, 2010, p. 48).

Inasmuch as cognitive legitimacy refers to the degree of which a practice can be understood according to existing cognitive schemas and cultural frameworks (Humphreys, 2010), sauna 
is critical in the quest for reconnecting with nature that pervades Finnish nation branding discourses.

\section{Discussion}

This study shows a dynamic account of discursive relations, furthering understandings of how symbolic cultural resources and discursive practices co-constitute place brands through bottom-up processes of legitimation work. The analysis of how discursive activity surrounding the symbolic resource of sauna constitutes the institutional structures of Finnish national identity at three levels (regulative, normative and cognitive) that we respectively label - sauna governance, communal identity creation and mythmaking. Examining how Finnish nation branding discourses and imaginaries produce three types of internal legitimacy work, we extend prior legitimation research (Cassinger et al., 2016; Eshuis and Edwards, 2013; Humphreys, 2010; Humphreys and LaTour, 2013; Lucarelli, 2018), theorising how local inhabitants actuate legitimating discourses; that is, how they negotiate regulative legitimacy, affirm normative legitimacy and mobilise cultural-cognitive legitimacy. Across each level, Finnish nation branding discourses were both affirmed and contested. With regard to the former, communal identity creation finds its foothold in Nordic principles of egalitarianism and communality. The ethos of egalitarianism and consensus culture manifest through normative standards of behaviour and practices at the social level. Historically, sauna has been linked to ideals of cleanliness and purity. While this shifted in the mid-20th century to reflect the aforementioned communal social experience, remnants of its historical meaning linger in contemporary conceptions of sauna as mythical, holy and spiritual. Such affirmations were evidenced in inhabitants' talk, but are also reflected in Finnish legislation, business practices, and architectural structures. A case in point - to this day, Saturday is characterised as sauna day and is embedded in Finnish legislation through collective labour agreements (Finland, 2018, p. 9).

This suggests that some forms of nation branding discourses, those of which are integrated with public diplomacy in an overall consensus-based framework (Szondi, 2008), are not only used to form external legitimacy amongst foreign constituents (Cassinger et al., 2016), but can also be used as a form of internal legitimacy work. Leveraging the symbolic resource of sauna, nation branding discourses become a neoliberal mode of governing (Jansen, 2008; Lucarelli and Giovanardi, 2014), significant particularly as policymakers begin to acknowledge the role of residents as important brand ambassadors (Braun et al., 2013). Here, national self-image becomes an internal policy instrument that shapes peoples' actions to maximise social and cultural endowments amidst institutional structures, ultimately, leading to communal (i.e. Finnish) identification (Szondi, 2008, p. 6). From this perspective, internal stakeholders may be used as a policy instrument to advance the common acceptance of urban policy linked to place branding. Most studies that examine the connection between nation branding and public diplomacy fall within what Kaneva (2011) characterises as technical-economic or political approaches. The current study takes a cultural approach vis-à-vis local discursive practices surrounding the symbolic resource of sauna.

Acceptance however, was neither total nor unilateral, and instances of contestation were witnessed, for example, in inhabitants' skirting of public policies (regarding gender segregation and alcohol prohibitions), traditional bureaucracy and neoliberal pressures affiliated with urbanisation. This brings to light the boundary conditions of cultural and symbolic constraints, which can be contested via discursive practices to co-constitute meanings of sauna as an arbitrator of Finnish branding discourse. While our findings show that sauna is used to foster inclusiveness and communal relationships internally, the
Legitimating the Finnish place brand

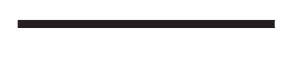


cultural artefact of sauna becomes entangled with Finnish national identity in other ways as politicians use the sauna to foster friendships with external stakeholders from abroad in what is commonly referred to as "sauna diplomacy" (Ministry for Foreign Affairs, 2011). Future research may investigate the ways that the political elite use sauna for policy and commercial decision-making (Saarenmaa, 2014) and interrogate how these complement and/ or conflict with internal stakeholders.

This conceptualisation of legitimation work highlights that discursive practices are in a dynamic interplay of consensus and contestation, adding greater nuance to the discussion of the co-constitution and legitimisation of place branding discourses, in particular, and the processes of legitimation work, more generally. Indeed, the costs of legitimacy shortfalls can be substantial for place branding campaigns (Sevin, 2011); therefore, studies that analyse language and internal legitimacy may have practical benefits. Researchers interested in disputes over national identity may find that it can be explained, at least in part, by the lack of inclusive participation and opportunities for internal legitimation work. For instance, it could be interesting to examine what sort of place-specific cultural practices emerge in Britain to legitimise the national identity in the wake of exiting the European Union.

\section{Conclusions}

This research has important implications regarding the role of internal legitimacy, which is an intrinsic, yet often overlooked aspect of the place branding process. Drawing on local accounts as well as other relevant data sources (e.g. books, articles, advertisements), we find that some forms of place branding are also forms of legitimation work and imply the entanglement of symbolic resources therein. Finnish nation branding discourses are interwoven with sauna as the symbolic resource of "Finnishness", co-constituting the fabric of legitimisation (Jansen, 2008). A limitation of our study is that it focused on sauna as a Finnish phenomenon, but saunas are common in neighbouring countries of Russia, Sweden and even Norway and other researchers may explore the implications for place branding as sauna spans over areas larger than a single locality. Despite the fact that the nation branding discourses and imaginaries in the present study are specifically Finnish, we allow ourselves to speak in terms of "Nordic place branding". We find that some of the sauna imaginaries pertaining to Finnish national discourse is inscribed in a broader framework of Nordic references (Pietilä et al., 2019). Our analysis of sauna as a symbolic resource for Finnish nation branding discourse leans heavily on a Nordic cultural heritage of governance, collectivism and romantic nostalgia for nature. Thus, findings from this study are relevant for theoretical development on the role of symbolic resources and related cultural elements in place branding discourses.

\section{References}

Acerbi, G. (1802), Travels through Sweden, Finland, and Lapland to the North Cape in the Years 1798 and 1799, Joseph Mawman, London.

Askegaard, S. and Linnet, J.T. (2011), "Towards an epistemology of consumer culture theory: phenomenology and the context of context", Marketing Theory, Vol. 11 No. 4, pp. 381-404.

Bell, F. (2016), “Looking beyond place branding: the emergence of place reputation”, Journal of Place Management and Development, Vol. 9 No. 3, pp. 247-254.

Belk, R., Fischer, E. and Robert, V.K. (2013), Qualitative Marketing and Consumer Research, Sage, London.

Belk, R.W., Wallendorf, M. and Sherry, J.F. Jr, (1989), "The sacred and the profane in consumer behaviour: theodicy on the odyssey", Journal of Consumer Research, Vol. 16 No. 1, pp. 1-38. 
Bianchini, F. and Ghilardi, L. (2007), "Thinking culturally about place”, Place Branding and Public Diplomacy, Vol. 3 No. 4, pp. 280-286.

Bosworth, M. (2013), "Why Finland loves sauna”, BBC News, 1 October, available at: www.bbc.com/ news/magazine-24328773

Braun, E., Kavaratzis, M. and Zenker, S. (2013), "My city-my brand: the different roles of residents in place branding", Journal of Place Management and Development, Vol. 6 No. 1, pp. 18-28.

Brown, A.D. and Toyoki, S. (2013), "Identity work and legitimacy", Organization Studies, Vol. 34 No. 7 , pp. 875-896.

Cassinger, C. and Eksell, J. (2017), "The magic of place branding: regional brand identity in transition", Journal of Place Management and Development, Vol. 10 No. 3, pp. 202-212.

Cassinger, C., Lucarelli, A. and Gyimothy, S. (2018), "Place branding: a Nordic perspective", The 3rd Annual Conference of the International Place Branding Association, available at: http://lup.lub.lu. se/record/46b9d67b-fd51-4e1a-9f45-4f9e5ab4445a

Cassinger, C., Merkelsen, H., Eksell, J. and Rasmussen, R.K. (2016), "Translating public diplomacy and nation branding in Scandinavia: an institutional approach to the cartoon crises", Place Branding and Public Diplomacy, Vol. 12 Nos 2/3, pp. 172-186.

Charters, S. and Spielmann, N. (2014), "Characteristics of strong territorial brands: the case of champagne”, Journal of Business Research, Vol. 67 No. 7, pp. 1461-1467.

Dzenovska, D. (2005), "Remaking the nation of Latvia: anthropological perspectives on nation branding", Place Branding, Vol. 1 No. 2, pp. 173-186.

Edelsward, L.M. (1991), “We are more open when we are naked”, Ethnos, Vol. 56 Nos 3/4, pp. 189-201.

Eshuis, J. and Edwards, A. (2013), "Branding the city: the democratic legitimacy of a new mode of governance”, Urban Studies, Vol. 50 No. 5, pp. 1066-1082.

Fairclough, N. (1989), Language and Power, Longman, London and New York, NY.

Fairclough, N. (1995), Critical Discourse Analysis: The Critical Study of Language, Longman, Essex.

Finland (2018), "Ahtausalan teknisten toimihenkilöiden työehtosopimus [collective agreement for technical staff]", p. 9, viewed 13 December 2020, available at: www.proliitto.fi/sites/default/files/ user_files/Tessit/TES2016_2018/ahtausalan_teknisten_toimihenkiloiden_tyoehtosopimus_1.2. 2017-31.1.2018_suojattu.pdf

Foucault, M. (1995/1975), Discipline and Punish: The Birth of the Prison, Sheridan, A. (trans.), Vintage, New York, NY.

Giovanardi, M., Lucarelli, A. and Pasquinelli, C. (2013), "Towards brand ecology: an analytical semiotic framework for interpreting the emergence of place brands", Marketing Theory, Vol. 13 No. 3, pp. 365-383.

Graan, A. (2013), "Counterfeiting the nation? Skopje 2014 and the politics of nation branding in Macedonia”, Cultural Anthropology, Vol. 28 No. 1, pp. 161-179.

Hannuksela, M.L. and Ellahham, S. (2001), "Benefits and risks of sauna bathing", The American Journal of Medicine, Vol. 110 No. 2, pp. 118-126.

Heikkinen, S. (2014), "Viinassa marinoituja omenoita ja venäläistä saippuaa - muistoja yleisistä saunoista”, Yle, 28 April, available at: https://yle.fi/aihe/artikkeli/2014/04/28/viinassamarinoituja-omenoita-ja-venalaista-saippuaa-muistoja-yleisista

Hirschman, E.C., Ruvio, A. and Belk, R.W. (2012), "Exploring space and place in marketing research: excavating the garage", Marketing Theory, Vol. 12 No. 4, pp. 369-389.

Humphreys, A. (2010), "Semiotic structure and the legitimation of consumption practices: the case of casino gambling", Journal of Consumer Research, Vol. 37 No. 3, pp. 490-510.

Humphreys, A. and LaTour, K.A. (2013), "Framing the game: assessing the impact of cultural representations on consumer perceptions of legitimacy", Journal of Consumer Research, Vol. 40 No. 4, pp. 773-795.
Legitimating the Finnish place brand 
Ilmonen, K. (1988), “Interview”, Helsingin Sonomat, 31 December, available at: www.hs.fi/aikakone/

Jansen, S.C. (2008), "Designer nations: neo-liberal nation branding - brand Estonia”, Social Identities, Vol. 14 No. 1, pp. 121-142.

Järvinen, I.R. (2010), Kalevala Guide, Suomalaisen Kirjallisuuden Seura, Helsinki.

Kaneva, N. (2011), "Nation branding: toward an agenda for critical research", International Journal of Communication, Vol. 5, p. 25.

Kaups, M. (1963), "The Finnish sauna: a cultural index to settlement", Annals of the Association of American Geographers, Vol. 53 No. 4, pp. 494-504.

Kavaratzis, M. and Hatch, M.J. (2013), "The dynamics of place brands: an identity-based approach to place branding theory", Marketing Theory, Vol. 13 No. 1, pp. 69-86.

Kavaratzis, M. and Kalandides, A. (2015), "Rethinking the place brand: the interactive formation of place brands and the role of participatory place branding", Environment and Planning A: Economy and Space, Vol. 47 No. 6, pp. 1368-1382.

Kirby, W.F. (1907), Kalevala, Vol. 1, E.P. Everyman's Library, London.

Kjeldgaard, D. and Östberg, J. (2007), "Coffee grounds and the global cup: glocal consumer culture in Scandinavia", Consumption Markets and Culture, Vol. 10 No. 2, pp. 175-187.

Koller, V. (2008), "The world in one city': semiotic and cognitive aspects of city branding”, Journal of Language and Politics, Vol. 7 No. 3, pp. 431-450.

Lichrou, M., O’Malley, L. and Patterson, M. (2017), "Making Santorini: reflecting on the past, imagining the future", Journal of Place Management and Development, Vol. 10 No. 2, pp. 106-120.

Lucarelli, A. (2018), "Place branding as urban policy: the (im) political place branding", Cities, Vol. 80, pp. 12-21.

Lucarelli, A. and Berg, P.O. (2011), "City branding: a state-of-the-art review of the research domain”, Journal of Place Management and Development, Vol. 4 No. 1, pp. 9-27.

Lucarelli, A. and Brorström, S. (2013), "Problematising place branding research: a meta-theoretical analysis of the literature", The Marketing Review, Vol. 13 No. 1, pp. 65-81.

Lucarelli, A. and Giovanardi, M. (2014), "The political nature of brand governance: a discourse analysis approach to a regional brand building process", Journal of Public Affairs, Vol. 16 No. 1, pp. 16-27.

Messely, L., Rogge, E. and Dessein, J. (2013), "Using the rural web in dialogue with regional stakeholders", Journal of Rural Studies, Vol. 32, pp. 400-410.

Ministry for Foreign Affairs (2011), "Finnish Sauna society recognizes the sauna diplomacy of the foreign ministry", Valtioneuvosto, 13 June, available at: https://valtioneuvosto.fi/en/article/-/ asset_publisher/suomen-saunaseura-palkitsi-ulkoministerion-saunadiplomatian

Morgan, N.J., Pritchard, A. and Piggott, R. (2003), "Destination branding and the role of the stakeholders: the case of New Zealand", Journal of Vacation Marketing, Vol. 9 No. 3, pp. 285-299.

Otnes, C.C. and Maclaran, P. (2018), "Royalty: Marketplace icons", Consumption Markets and Culture, Vol. 21 No. 1, pp. 65-75.

Peltonen, M. (2000), "Between landscape and language: the Finnish national self-image in transition", Scandinavian Journal of History, Vol. 25 No. 4, pp. 266-280.

Phillips, N., Lawrence, T.B. and Hardy, C. (2004), "Discourse and institutions", Academy of Management Review, Vol. 29 No. 4, pp. 635-652.

Pietilä, J., Tillotson, J.S. and Askegaard, S. (2019), "Mythologies of Finnishness in advertising", in Askegaard, S. and Östberg, J. (Eds), Nordic Consumer Culture, Palgrave Macmillan, Cham, pp. 239-265.

Pihkala, E. (1999), “The political economy of post-war Finland, 1945-1951”, Scandinavian Economic History Review, Vol. 47 No. 3, pp. 26-47. 
Rokka, J. (2017), “Champagne: Marketplace icon”, Consumption Markets and Culture, Vol. 20 No. 3, pp. 275-283.

Saarenmaa, L. (2014), "Playboys and politicians: Men's magazines as political counterpublics", in Starck, K. and Sauer, B. (Eds), A Man's World? Political Masculinities in Literature and Culture, Cambridge Scholars Publishing, Newcastle, pp. 181-194.

Särkikoski, T. (2012), Kinkaan Kutsu ja Löylyn Lumo. Suomalaisen Saunomisen Vuosikymmeniä, Suomen Saunaseura, Jelgava Printing House, Latvia.

Scott, W.R. (1995), Institutions and Organizations, Sage, Thousand Oaks, CA.

Sevin, E. (2011), "Thinking about place branding: ethics of concept", Place Branding and Public Diplomacy, Vol. 7 No. 3, pp. 155-164.

Spiggle, S. (1994), "Analysis and interpretation of qualitative data in consumer research", Journal of Consumer Research, Vol. 21 No. 3, pp. 491-503.

Suchman, M.C. (1995), "Managing legitimacy: strategic and institutional approaches", Academy of Management Review, Vol. 20 No. 3, pp. 571-610.

Szondi, G. (2008), "Public diplomacy and nation branding: conceptual similarities and differences", Discussion Papers in Diplomacy, Clingendael Netherlands Institute of International Relations, Hague.

Thomas, T.C., Price, L.L. and Schau, H.J. (2013), "When differences unite: resource dependence in heterogeneous consumption communities", Journal of Consumer Research, Vol. 39 No. 5, pp. 1010-1033.

Tillotson, J.S. and Martin, D.M. (2015), "Myth-mediated branding", in Thyroff, A.E., Murray, J.B. and Belk, R.W. (Eds), Consumer Culture Theory, Emerald Group Publishing Limited, Bingley, pp. 189-221.

Varga, S. (2013), "The politics of nation branding: collective identity and public sphere in the neoliberal state", Philosophy and Social Criticism, Vol. 39 No. 8, pp. 825-845.

Warnaby, G. and Medway, D. (2013), "What about the 'place' in place marketing?”, Marketing Theory, Vol. 13 No. 3, pp. 345-363.

Weijo, H.A., Martin, D.M. and Arnould, E.J. (2018), "Consumer movements and collective creativity: the case of restaurant day", Journal of Consumer Research, Vol. 45 No. 2, pp. 251-274.

Zenker, S. and Erfgen, C. (2014), "Let them do the work: a participatory place branding approach", Journal of Place Management and Development, Vol. 7 No. 3, pp. 225-234.

\section{Corresponding author}

Jack S. Tillotson can be contacted at: jack.tillotson@uwasa.fi
Legitimating the Finnish place brand 